\title{
Extension of the Storage and Post-Storage Life of Tuberose (Polianthes tuberosa L.) Loose Flowers cv. 'Local'
}

\author{
Parag Babaji Jadhav" and Nikhil Pradip Gurav
}

Agril Research Expert and Agri. Res. Asso., Ecofrost Technologies Pvt. Ltd., Survey No 134/1, 134/2,130/3, Jeevan Nagar, Tathawade, Pune, Maharashtra-411 033, India

*Corresponding author

\section{A B S T R A C T}

\begin{tabular}{|l|}
\hline K e y w o r d s \\
Tuberose, Loose, \\
$\begin{array}{l}\text { Sucrose, GA }, \text {, Silver, } \\
\text { STS, Storage Life, }\end{array}$ \\
$\begin{array}{l}\text { Flower, Ecofrost, Local, } \\
\text { Cold, etc. }\end{array}$ \\
\hline Article Info \\
\hline $\begin{array}{l}\text { Accepted: } \\
\text { 20 December } 2017 \\
\text { Available Online: } \\
\text { 10 January } 2018\end{array}$ \\
\hline
\end{tabular}

\section{Introduction}

Tuberose is grown commercially in many countries including India, Kenya, Mexico, Morocco, France, Italy, Hawaii, South Africa, Taiwan, North Carolina, USA, Egypt, China and many other tropical and subtropical areas in the world. In India, commercial cultivation of Tuberose is popular in Bagnan, Kolaghat, Midnapur, Panskura, Ranaghat, Krishnanagar of West Bengal; Coimbatore and Madurai districts of Tamil Nadu; Pune, Nashik, Ahmednagar, Thane, Sangli of Maharashtra; East Godavari, Guntur, Chitoor, Krishna District of Andhra Pradesh; Mysore, Tumkur, Kolar, Belgaum and Devanhalli taluka in
Karnataka; Guwahati and Jorhat in Assam; Udaipur, Ajmer and Jaipur in Rajasthan; Navsari and Valsad of Gujarat and parts of Uttar Pradesh and Punjab. As per area and production statistics of the National Horticulture Board (http://nhb.gov.in/areapro/Indian\%20Horticulture\%202013.pdf), the total area under Tuberose cultivation in the country is about 7.95 lakh hectares. The production of loose and cut-flowers is estimated to be 27.71 ' $000 \mathrm{MT}$ ' and 1560.70 lakh (nos) respectively (http://vikaspedia.in/ agriculture/cropproduction/packageofpractices /flowers/tuberose\#section-25, 2013). In India, Tuberose is a very popular flower and millions upon millions of spikes are sold every year. 
Tuberose flowers are cultivated to produce flower spikes and loose flowers on a commercial scale for the domestic market. The Tuberose flowers are cultivated throughout the year and can be grown outdoor or under greenhouse conditions. The variety of flowers grown has also increased dramatically. Tuberose flowers are in demand for their elegant attractive spikes of different hues. Tuberoses can be easily grown with a little care and attention in beds for garden decoration and cut flowers in pots for interior and outdoor decoration.

Tuberose loose flowers are very sensitive to the stress of storage and transportation, particularly at warm temperatures. There are reports that improper post-harvest handling accounts for $20 \%$ to $30 \%$ of cut-flower loss during marketing. While production of highquality flowers is important, it is equally critical to handle the flowers properly after they are harvested from the field.

\section{Materials and Methods}

The present trial was carried out in the cold storage of Ecofrost Technologies Pvt. Ltd at the site of farmer, District Pune, Maharashtra, India - 412214 during the month of October 2017. The aim of this study was to examine the effect of a combination of $\mathrm{GA}_{3} @ 50 \mathrm{ppm}$ + Sucrose @ 1\% + Silver Thiosulphate (STS) @ $50 \mathrm{ppm}$ along with control on the postharvest storage-life of tuberose loose flower $c v$. 'Local'. The 2 treatments applied were tagged as $\mathrm{T}_{1}$ and $\mathrm{T}_{2}$ i.e. spray of $\mathrm{GA}_{3} @ 50$ ppm + Sucrose @ 1\% + Silver Thiosulphate (STS) @ 50 ppm $\left(\mathrm{T}_{2}\right)$ along with control $\left(\mathrm{T}_{1}\right)$.

The stage of separation of Tuberose loose flower depends on the distance from the market, where the flowers are to be sold. It is always preferable to separate the loose flowers in the morning hours. Immediately after separation, loose flowers were kept for $30 \mathrm{~min}$ in shade and then were put inside the cold storage. 3 crates of loose flowers $(7 \mathrm{~kg}$ loose flowers/crate) of Tuberose $c v$. "Local" were treated with light spray of the solution of $\left[\mathrm{GA}_{3}\right.$ @ $50 \mathrm{ppm}+$ Sucrose @ 1\% + Silver Thiosulphate (STS) @ $50 \mathrm{ppm}]\left(\mathrm{T}_{2}\right)$ and then first crate was placed at normal room conditions to measure the shelf life (days), second crate was placed in cold room for 8 hours to measure the pre-cooling life (days) and third crate was also placed at cold room to check the storage life (days) of the commodity.

$1 \mathrm{~kg}$ of flowers were taken out from the third crate inside the cold room on day 1 (just after treatment of flowers), at the end of day 1 , at the end of day 4 , at the end of day 6 , at the end of day 9 and at the end of day 12 to check the post storage life (days) in ordinary room conditions.

Three crates of loose flowers $(7 \mathrm{~kg}$ loose flowers/crate) of Tuberose $c v$. "Local" were treated with light spray of tap water $\left(\mathrm{T}_{1}\right)$ and out of them, the first crate was placed at room conditions to measure the shelf life (days), the second crate was placed inside the cold room for 8 hours to measure the life (days) after precooling and the third crate was also placed inside the cold room to check the storage life (days) of commodity.

$1 \mathrm{~kg}$ of flowers were taken out from the third crate from cold room on day 1 (just after treatment of flowers), at the end of day 1 , at the end of day 4 , at the end of day 6 , at the end of day 9 and at the end of day 12 to check the post storage life (days) in ordinary room conditions.

\section{Observations recorded}

The post-harvest shelf-life of loose flowers (days) at normal room conditions, storage life (days) inside cold room and the post-storage 
life (days) at room conditions were observed during the month of October 2017.

\section{Results and Discussion}

\section{Photos were taken in cold storage}

Post-storage life was recorded as 12 days for treated Tuberose loose flowers $\left(\mathrm{T}_{2}\right)$ stored at $4^{0} \mathrm{C}+93 \% \mathrm{RH}$. However, only 9 days was recorded in control $\left(\mathrm{T}_{1}\right)$ (Table 1 and Graph 1). After pre-cooling, storage life was recorded as 2.5 days for treated Tuberose loose flowers $\left(\mathrm{T}_{2}\right)$ kept at room conditions. Only 2.00 days was recorded in control $\left(\mathrm{T}_{1}\right)$ (Table 2 and Graph 1). Normal shelf life (days) of Tuberose loose flower was recorded as 1.50 days at room condition $\left(\mathrm{T}_{1}\right)$ (Table 3 ). Likewise, 2 days was recorded in $\mathrm{T}_{2}$.

Table.1 Storage life (days) of Tuberose loose flowers $c v .$, 'Local' inside the cold room (Ecofrost Technologies Pvt. Ltd., Pune)

\begin{tabular}{|l|c|c|}
\multicolumn{1}{|c|}{ Treatment Details } & Set points & $\begin{array}{c}\text { Cold storage life } \\
\text { (Days) }\end{array}$ \\
\hline Tuberose loose flowers (Control-T $)$ & $4^{0} \mathrm{C}+93 \% \mathrm{RH}$ & 9.00 \\
\hline Tuberose loose flowers (With treatment-T & $4^{0} \mathrm{C}+93 \% \mathrm{RH}$ & 12.00 \\
\hline
\end{tabular}

Table.2 Pre-cooling life (days) of Tuberose loose flowers cv. 'Local' in ordinary room conditions, after produce held inside the cold room conditions for 8 hours

\begin{tabular}{|l|c|c|}
\hline \multicolumn{1}{|c|}{ Treatment Details } & $\begin{array}{c}\text { Precooling set point } \\
\text { for Tuberose loose } \\
\text { flowers }\end{array}$ & $\begin{array}{c}\text { Pre-cooling life } \\
\text { (Days) in ordinary } \\
\text { room conditions }\end{array}$ \\
\hline Tuberose loose flowers (Control-T T $_{1}$ ) & $4^{0} \mathrm{C}+93 \% \mathrm{RH}$ & 2.00 \\
\hline Tuberose loose flowers (With treatment-T & $4^{0} \mathrm{C}+93 \% \mathrm{RH}$ & 2.50 \\
\hline
\end{tabular}

Table.3 Shelf-life (days) of Tuberose loose flowers cv. 'Local' in ordinary room conditions

\begin{tabular}{|c|}
\hline Treatment Details \\
\hline Tuberose loose flowers $\left(\mathrm{T}_{1}\right)$ \\
\hline Tuberose loose flowers $\left(\mathrm{T}_{2}\right)$ \\
\hline
\end{tabular}

\begin{tabular}{|c|}
$\begin{array}{c}\text { Shelf life (Days) in ordinary room } \\
\text { conditions }\end{array}$ \\
1.50 \\
2.00 \\
\hline
\end{tabular}

Table.4 Post-storage life (Days) of Tuberose loose flowers cv. 'Local' in ordinary room conditions

\begin{tabular}{|c|c|c|}
$\begin{array}{c}\text { On days flowers were taken out from cold } \\
\text { storage and put at room conditions }\end{array}$ & $\begin{array}{c}\text { Post-storage life } \\
\text { (Days) at room } \\
\text { conditions }\left(\mathrm{T}_{1}\right)\end{array}$ & $\begin{array}{c}\text { Post-storage life } \\
\text { (Days) at room } \\
\text { conditions }\left(\mathrm{T}_{2}\right)\end{array}$ \\
\hline $1^{\text {st }}$ day (at initial start point) & 1.50 & 2.00 \\
\hline At end of $\mathbf{1}^{\text {st }}$ day & 2.00 & 2.50 \\
\hline At the end of $4^{\text {th }}$ day & 2.00 & 2.50 \\
\hline At the end of $\mathbf{6}^{\text {th }}$ day & 1.50 & 2.00 \\
\hline At the end of $9^{\text {th }}$ day & 1.00 & 1.50 \\
\hline At the end of $\mathbf{1}^{\text {th }}$ day & 0.50 & 1.00 \\
\hline
\end{tabular}



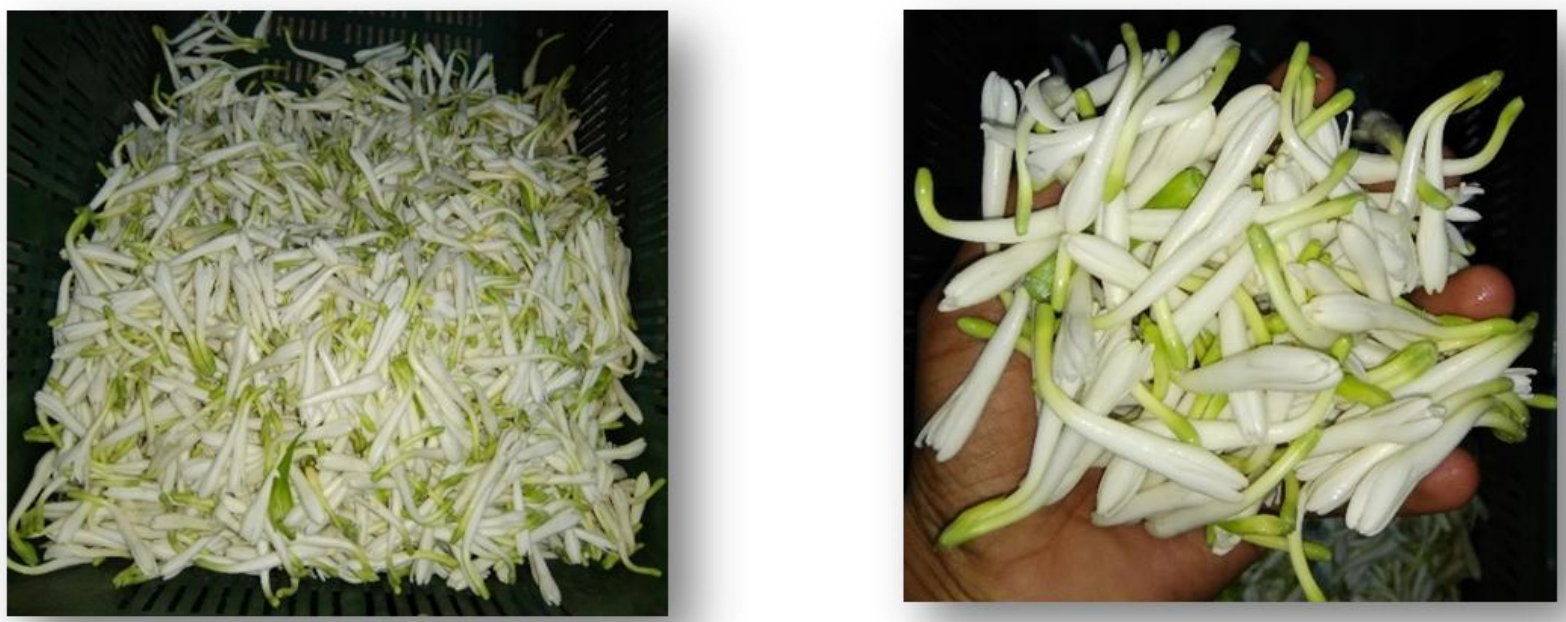

Photo.1 $1^{\text {st }}$ Day Photos (09-10-2017) (T 1 - Tap water spray)
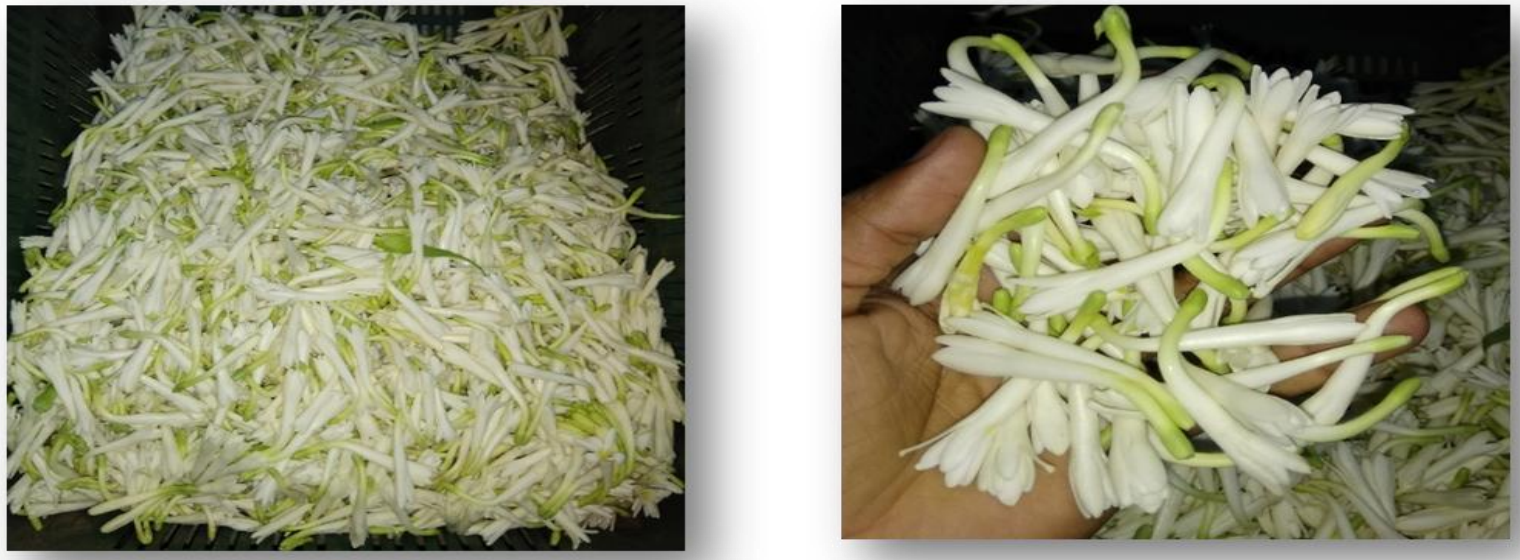

Photo. $4^{\text {th }}$ Day Photos (12-10-2017) $\left(\mathrm{T}_{1}\right.$-Tap water spray)
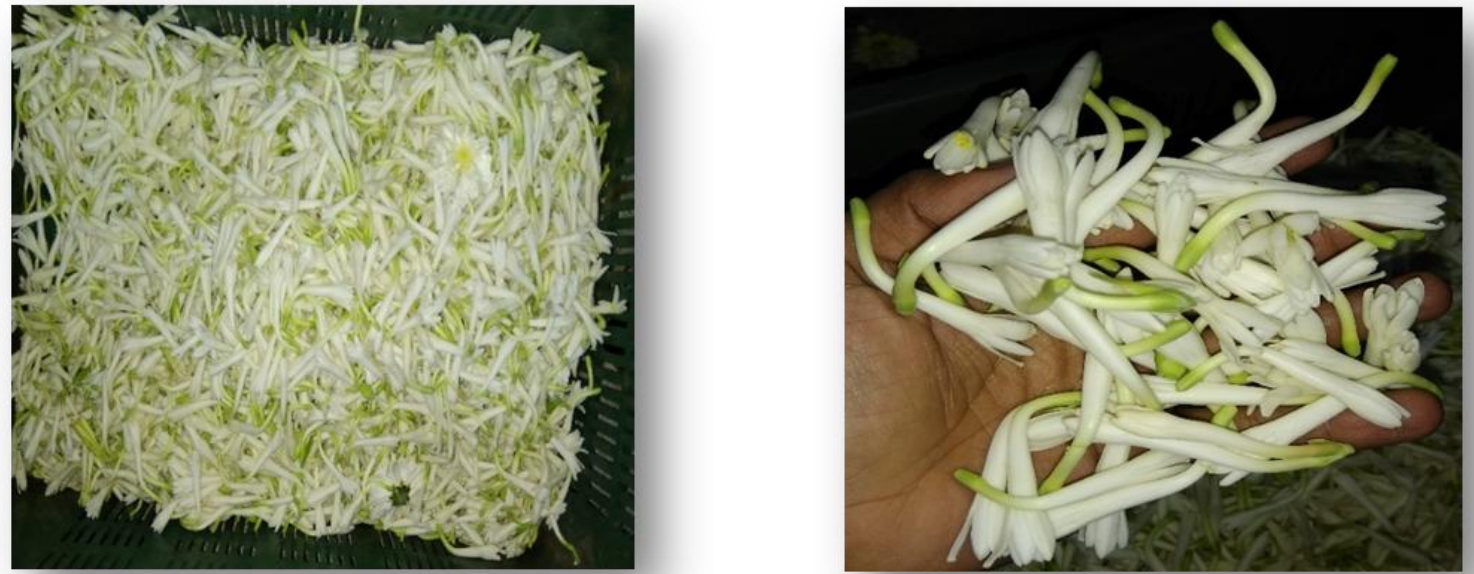

Photo.3 $6^{\text {th }}$ Day Photos (14-10-2017) $\left(\mathrm{T}_{1}\right.$-Tap water spray) 

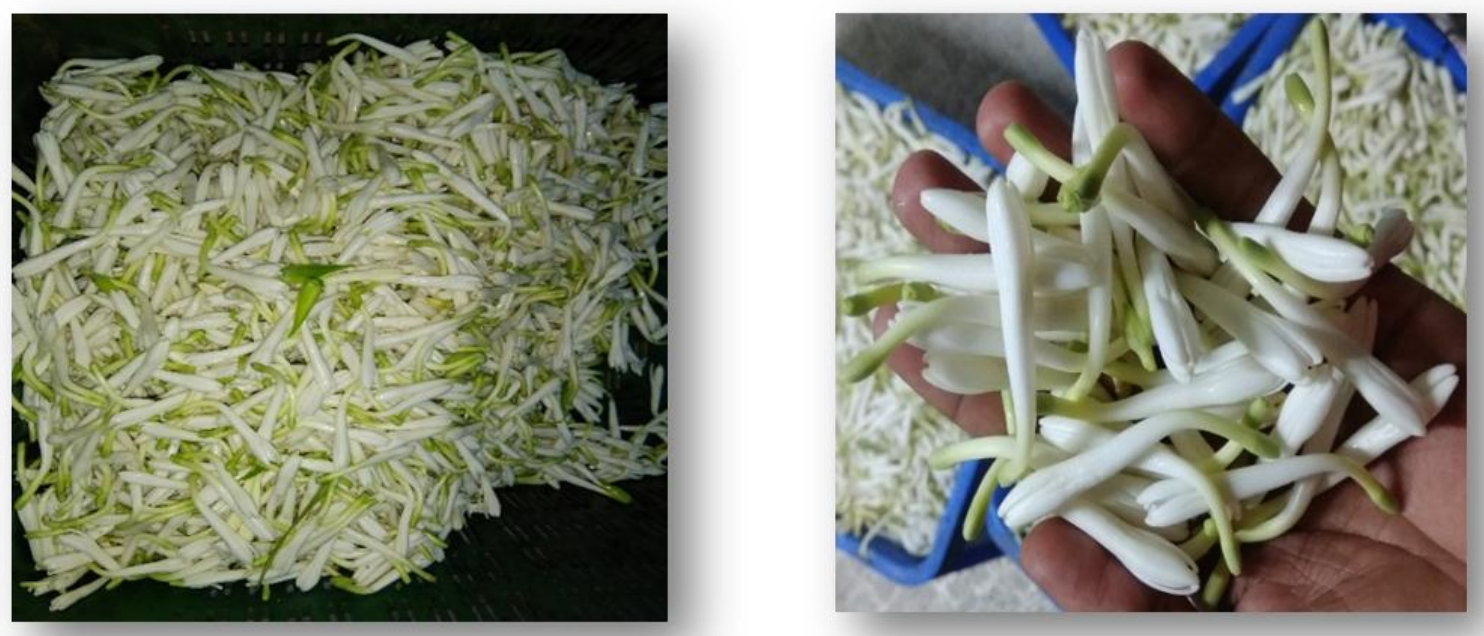

Photo.4 $1^{\text {st }}$ Day Photos $\left(\mathrm{T}_{2}\right)$
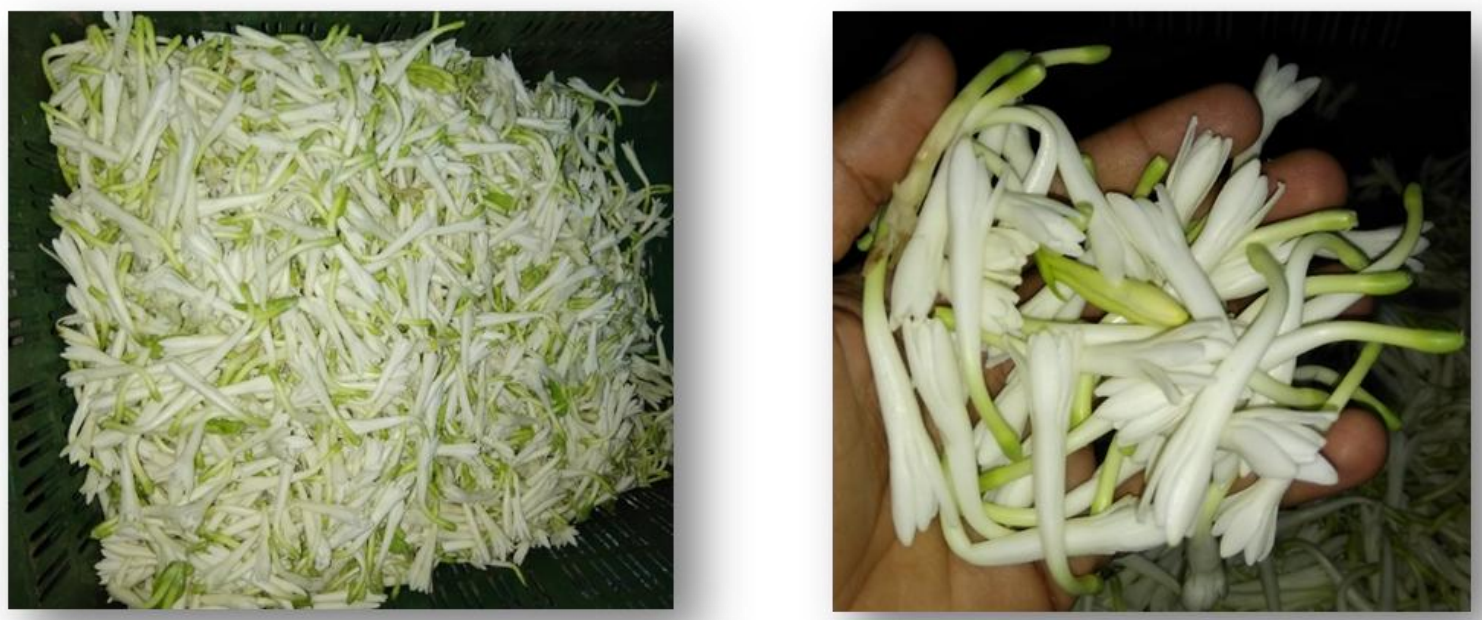

Photo.5 $4^{\text {th }}$ Day Photos $\left(\mathrm{T}_{2}\right)$
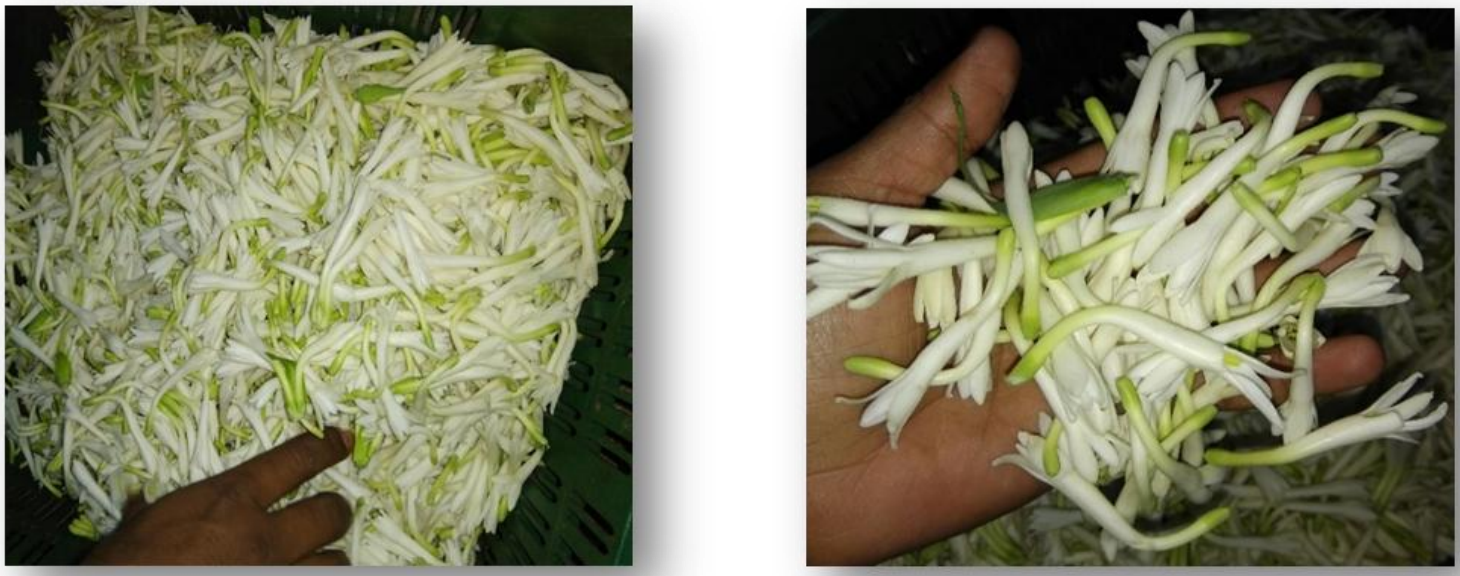

Photo.6 $6^{\text {th }}$ Day Photos $\left(\mathrm{T}_{2}\right)$ 
Photo.7 $\mathrm{T}_{1}$ (Tap water spray): Un-treated flowers were taken out on 09-10-2017 from cold storage \& put at room conditions. Photos were taken at the end of day $1,2 \& 3$

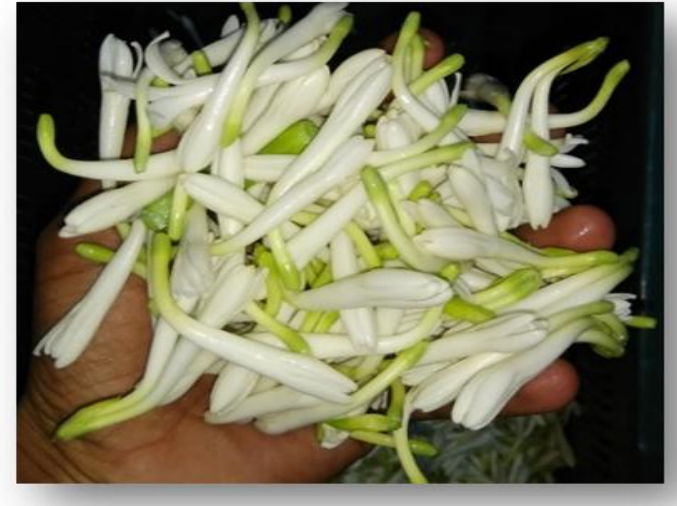

Day-I

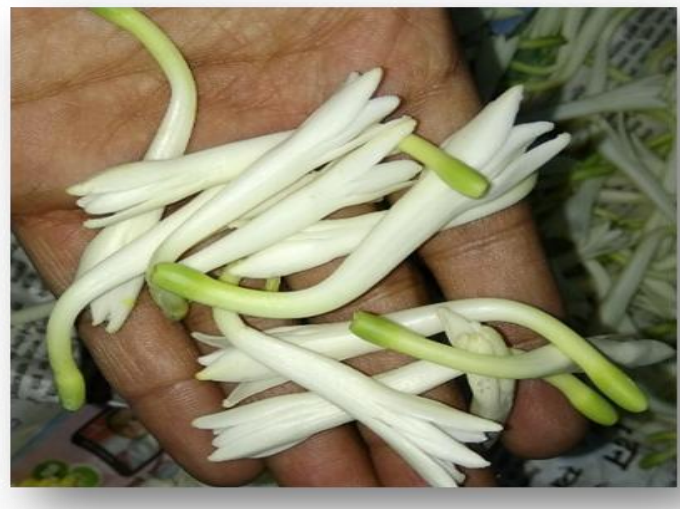

Day-II

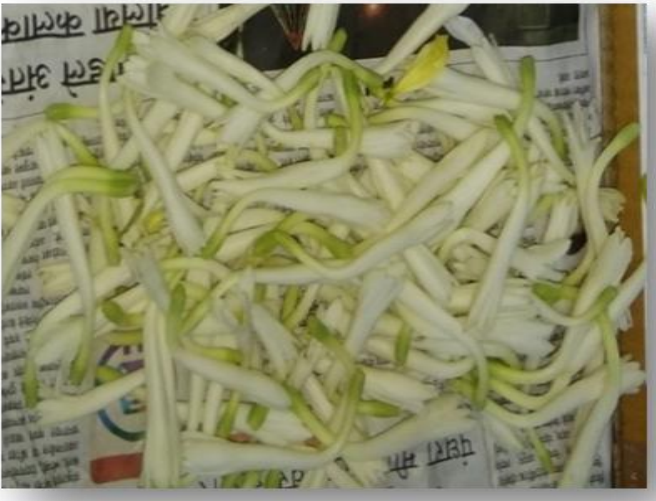

Day-III

Photo.8 $\mathrm{T}_{1}$-(Tap water spray): Un-treated flowers were taken out on 12-10-2017 from cold storage \& put at room conditions. Photos were taken at the end of 8 hours, $1^{\text {st }}$ day $\& 2^{\text {nd }}$ day

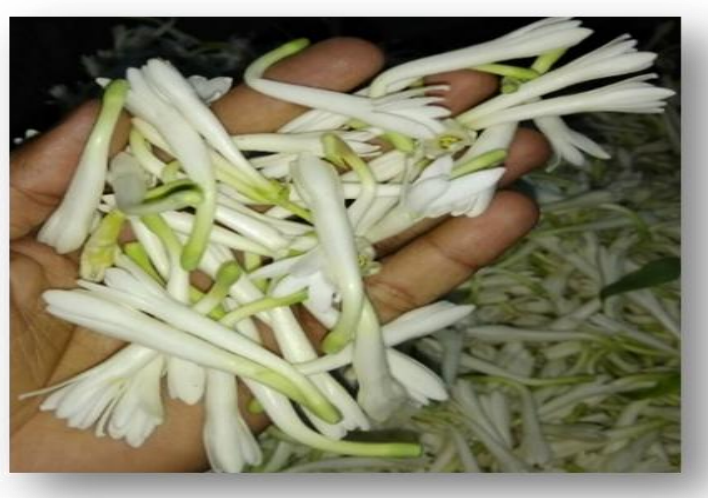

After 8 hours

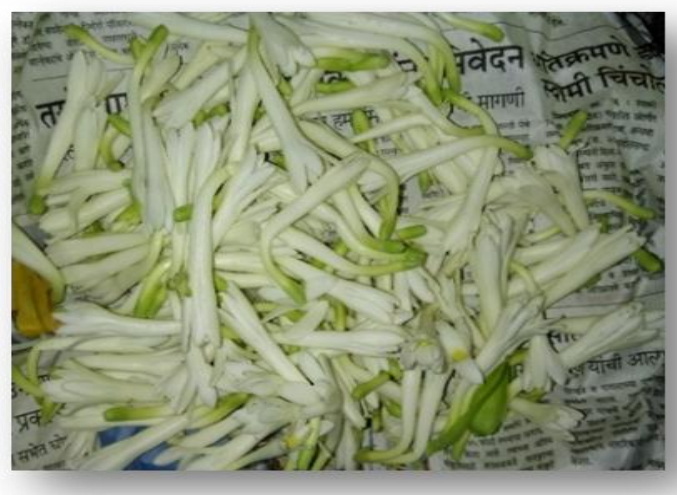

Day-I

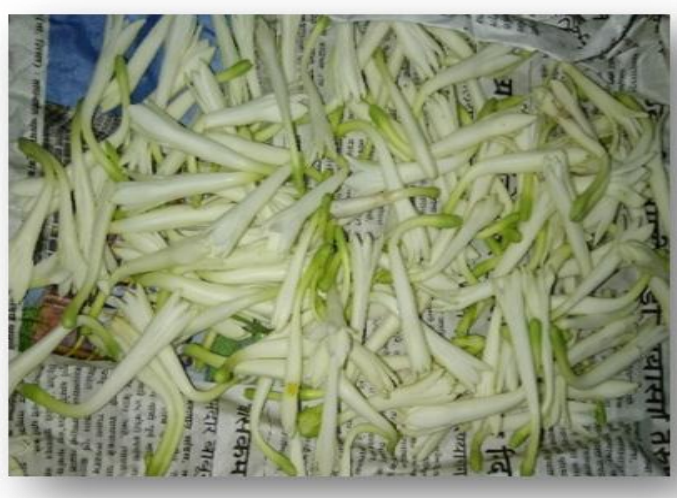

Day-II 
Photo.9 With treatment $\left(\mathrm{T}_{2}\right)$ : Treated flowers were taken out on 09-10-2017 from cold storage \& put at room conditions. Photos were taken at the end of $1^{\text {st }}, 2^{\text {nd }} \& 3^{\text {rd }}$ day. (Flowers treated with spray of mixture solution- GA $3 @ 50$ ppm + Sucrose @ $1 \%+$ Silver Thiosulphate (STS) @ 50 ppm)

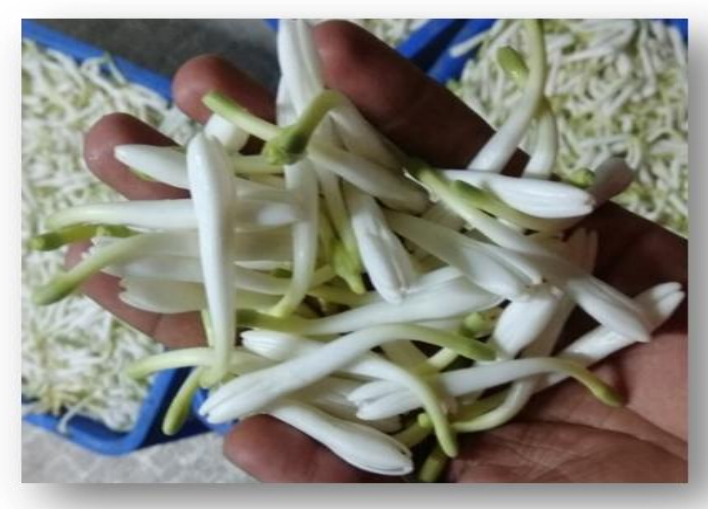

Day-I

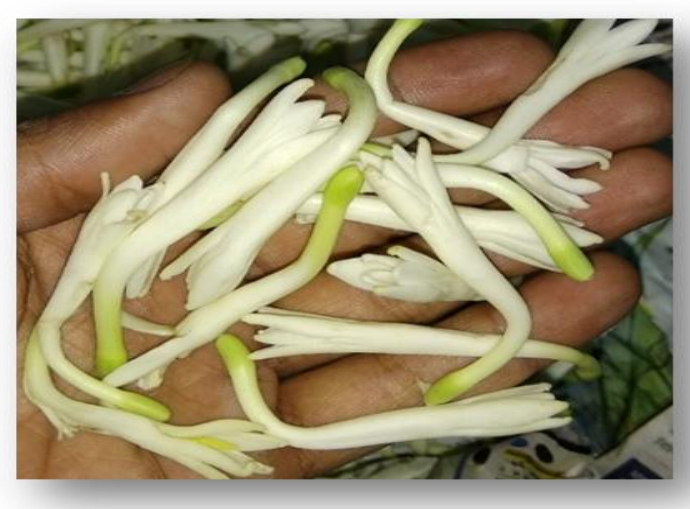

Day-II

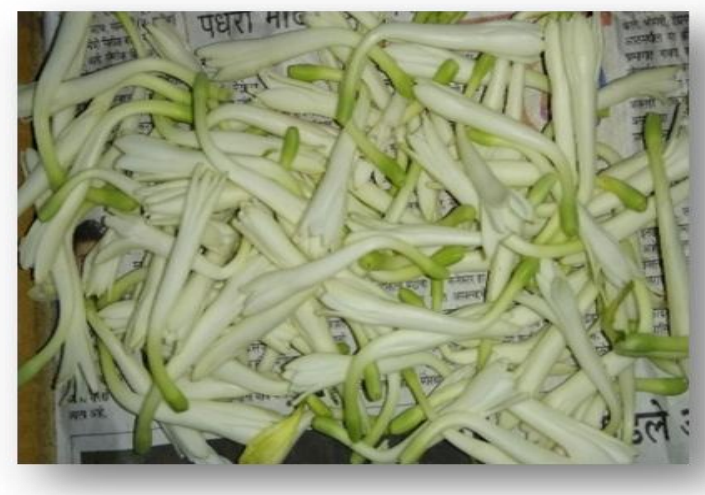

Day-III

Photo.10 With treatment $\left(\mathrm{T}_{2}\right)$ : Treated flowers were taken out on 12-10-2017 from cold storage \& put at room conditions. Photos were taken at the end of 8 hours, $1^{\text {st }}$ and $2^{\text {nd }}$ day. (Flowers treated with light spray of mixture solution- GA 3 @ 50 ppm + Sucrose @ $1 \%+$ Silver Thiosulphate (STS) @ 50 ppm)

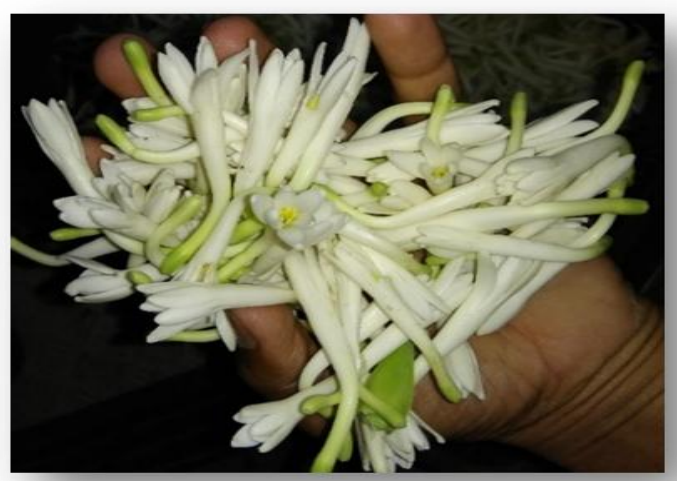

After 8 hours

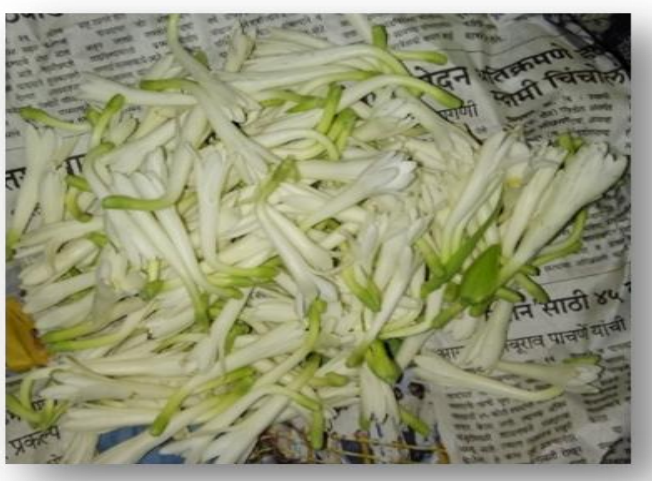

Day-I

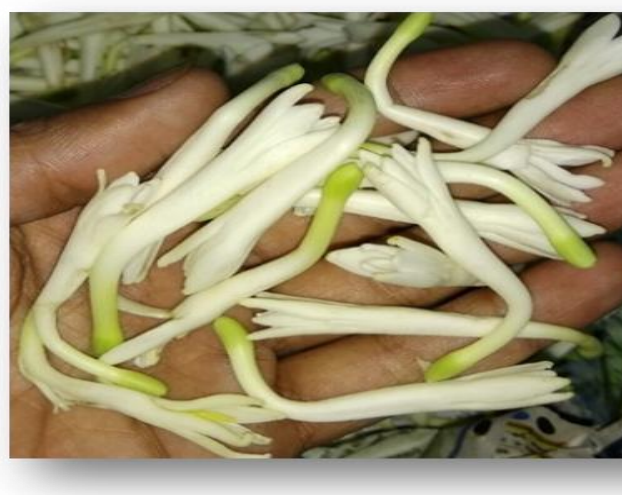

Day-II 
Graph.1 Storage and Post-storage life (Days) of Tuberose Loose Flowers $C v$. 'Local'

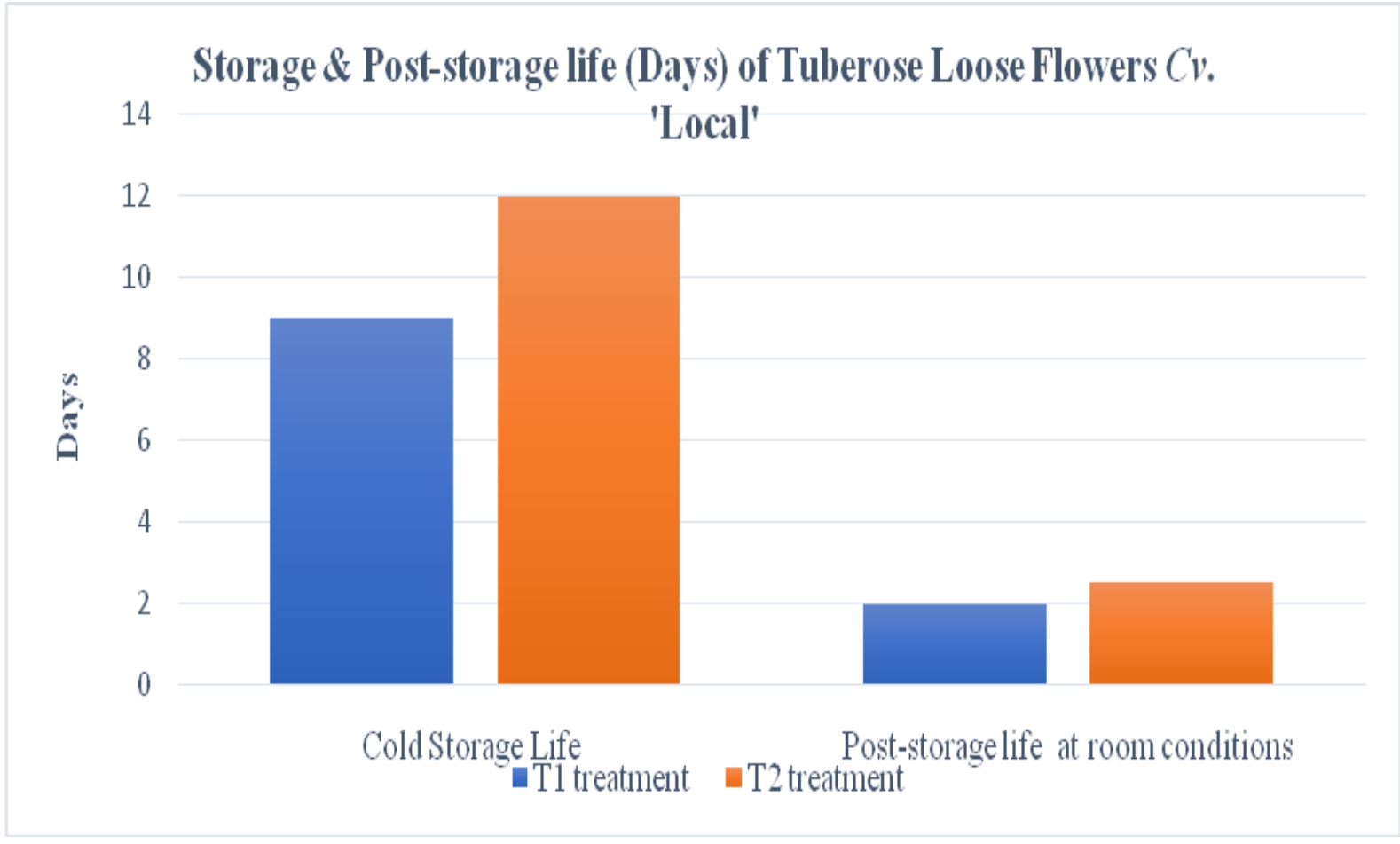

Graph.2 Tuberose loose flowers $c v$. 'Local' post-storage life (Days) at room conditions

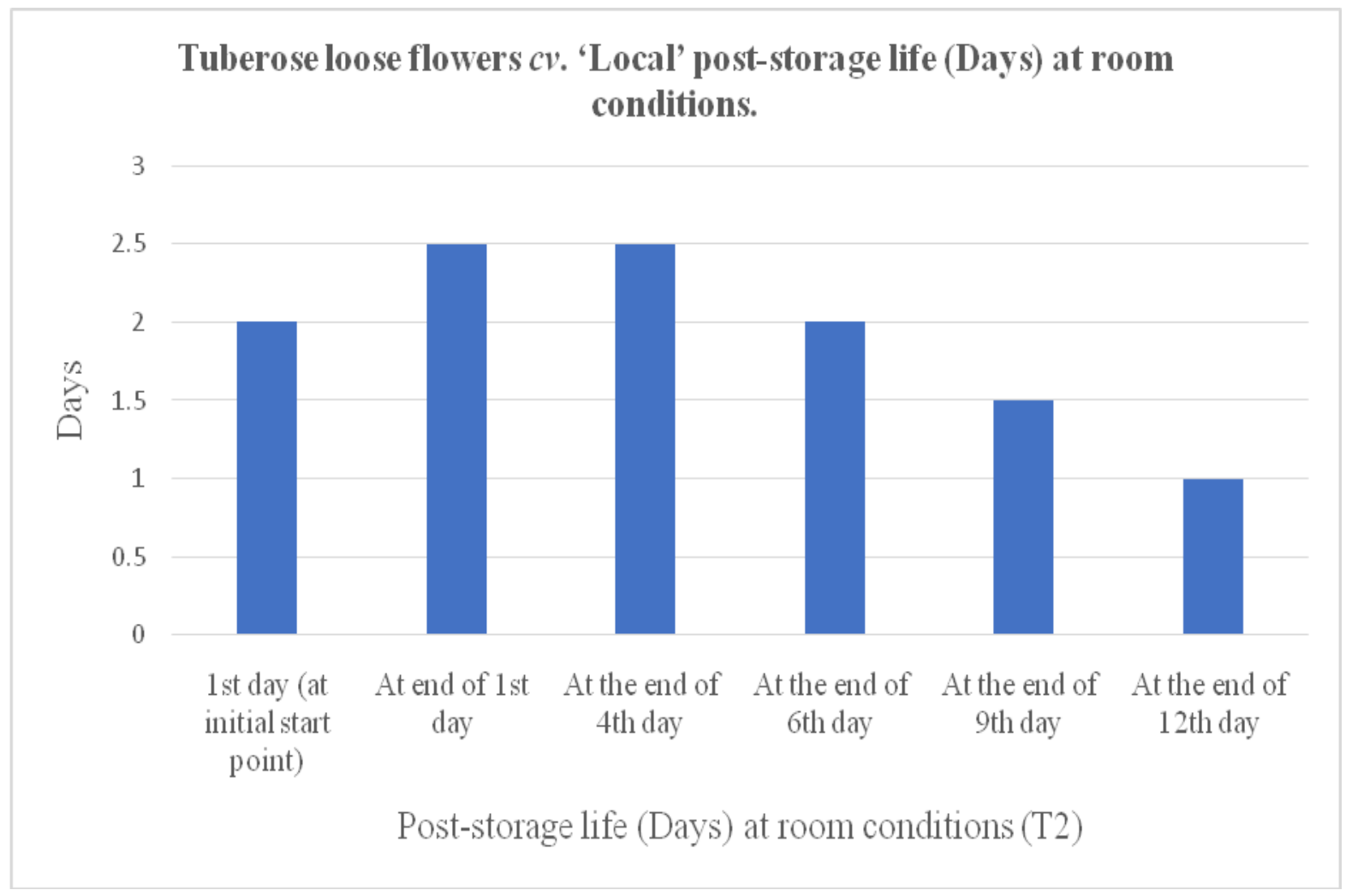


Graph.3 Tuberose loose flowers $c v$. 'Local' post-storage life (Days) at room conditions

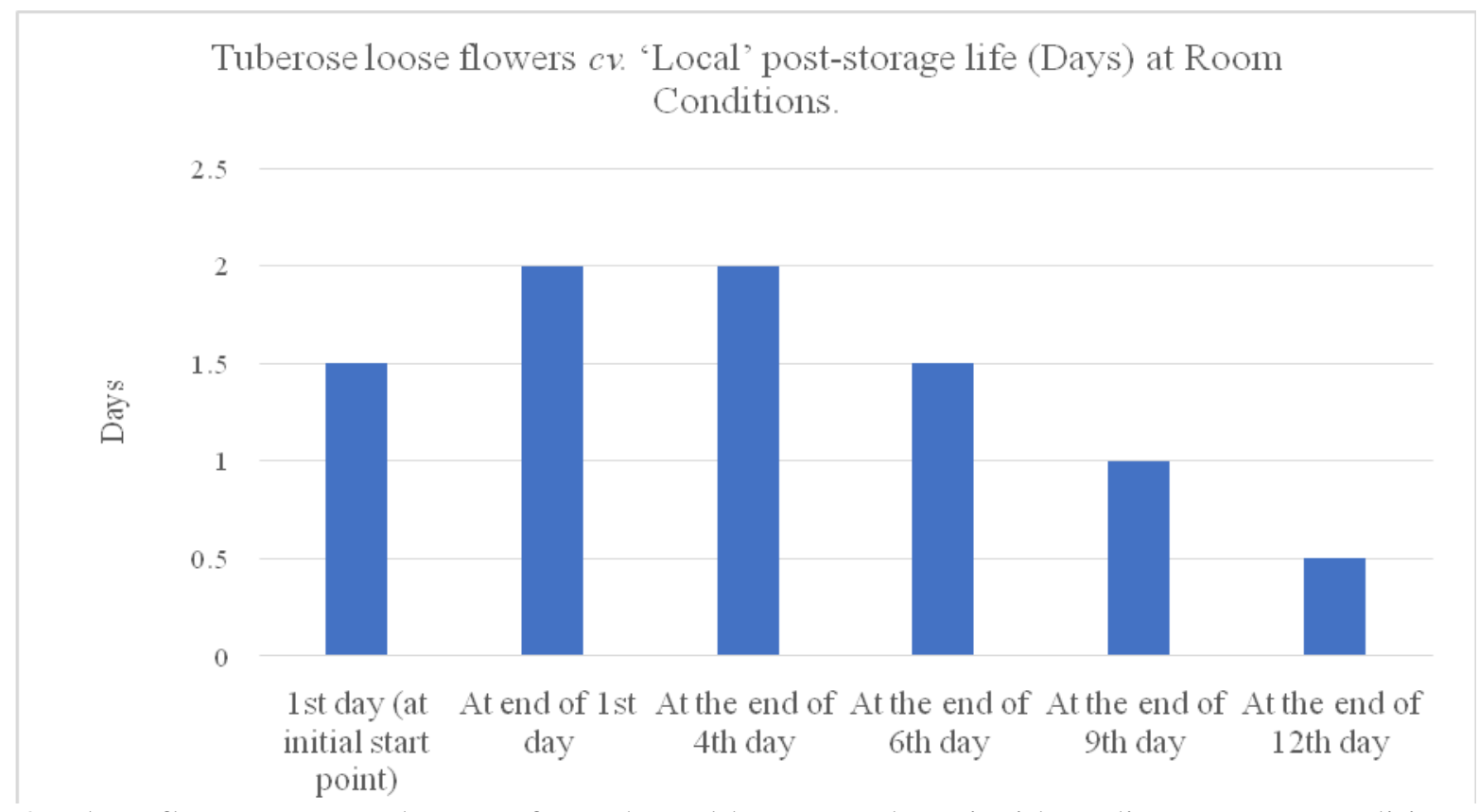

On days flowers were taken out from the cold room and put inside ordinary room conditions

$\left(\mathrm{T}_{1}\right)$

In table 4 (Graph 2 and 3), post-storage life (days) was recorded higher in $\mathrm{T}_{2}$ (chemical solution treated flowers) than control ( $\mathrm{T}_{1}$-tap water treated flowers). Withering of petals (untreated flowers) started on day 1.5 at room conditions, after loose flowers were taken out from cold room at the end of day 6 . Similarly, withering of petals (treated flowers) started on day 1.5 at room conditions, after these were taken out from cold storage at the end of day 9. Petal drying started inside cold room after end of the 11 days in storage for the untreated flowers $\left(T_{1}\right)$ and after end of the 14 days for the treated flowers $\left(T_{2}\right)$. Photo No. 1 to 6 show untreated and treated flowers inside the cold storage and Photo No. 7 to 10 show flowers taken out from the cold storage and kept in room conditions. None of the disease signs were recorded inside cold storage for treated flowers. Treated and untreated flowers were stored for more than 16 days, but the post storage life was recorded less than $6 \mathrm{hrs}$ in normal room conditions.
The addition of sugars in spray solution is essential for good flower development (Paulin, 1986). Sucrose feeding of loose flower causes an acceleration of enzyme activity and proline accumulation in the petals at the end of the vase-life. Recently, it has been suggested that in stress situations cells require more sugars to fulfil the energy and carbon needs for the defensive response to stress (Koizuka et al., 1995). Since, the cutflowers suffer from energy deficiency and are susceptible to different stresses, the demand for hexoses in petals might be satisfied partially by the hydrolysis of starch. Moreover, according to (Tirosh and Mayak, 1988 ), the activity of $\alpha$-amylase plays an important role in the mechanism of petal opening and regulates the senescence syndrome.

From the above discussion, it can be concluded that shelf life of Tuberose $c v$. 'Local' loose flowers was higher with $\mathrm{T}_{2}$ (light 
spray of $\mathrm{GA}_{3} @ 50$ ppm + Sucrose @ 1\% + Silver Thiosulphate (STS) @ 50 ppm (10ml per $\mathrm{kg}$ loose flowers)) than control $\mathrm{T}_{1}(10 \mathrm{ml}$ tap water per $\mathrm{kg}$ loose flowers) at room conditions. Similarly, storage life was higher in cold storage $\left(4^{0} \mathrm{C}+93 \% \mathrm{RH}\right)$ with $\mathrm{T}_{2}$ than $\mathrm{T}_{1}$. Post-storage life (days) was also recorded high in $\mathrm{T}_{2}$.

\section{References}

http://nhb.gov.in/areapro/Indian\%20Horticulture\%202013.pd $\mathrm{f}$

http://vikaspedia.in/agriculture/cropproductio $\mathrm{n}$ /packageofpractices/flowers/tuberose\# section-25, 2013.

Koizuka N, Tanaka Y, and Morochashi Y. Expression of $\alpha$-amylase in response to wounding in mung bean. Planta, 1995; 195:530-534.

Paulin, A. 1986. Influence of exogenous sugars the evolution of some senescence parameters in plants. Acta Horticulturae, 1986; 181:183-193.

Tirosh T, and Mayak S. Changes in starch content during the development of carnation petals. Journal of Plant Physiology, 1988; 113(3), 361-363.

\section{How to cite this article:}

Parag Babaji Jadhav and Nikhil Pradip Gurav. 2018. Extension of the Storage and Post-Storage Life of Tuberose (Polianthes tuberosa L.) Loose Flowers cv. 'Local'. Int.J.Curr.Microbiol.App.Sci. 7(01): 2798-2807. doi: https://doi.org/10.20546/ijcmas.2018.701.334 